\title{
Sea as A Location for Transaction: Buginese Pandeling in East Borneo
}

\author{
Harto Yuwono \\ Masyarakat Sejarawan Indonesia Jawa Tengah
}

\begin{abstract}
This research is about Buginese pandeling in east Borneo at sea as a location for transaction. Pandeling are used legally as well as economically to refer the activities that provided some guarantee of someone to another as a duty to get something. This transaction was one of economic interactions that based on social ties and traditions. Pandeling is a trade commodity in business and monetary transaction among the traders and capital investors. Pandeling came into the system without

Received:

16 June 2017

Accepted:

27 November 2017

Corresponding author:

hartoyu@yahoo.com prediction to be transferred and even had to separate from his family, if the new owner came from far away. According the formal regulation on this transaction, pandeling had to subordinate except he could pay off his debt with all rents. After his debt and rent was paid off by himself, pandeling did not often return to his original place but lived in his new settlement, place where he got his freedom. Therefore, this group will begin as a part of local community or build a new community as a free person.
\end{abstract}

Keywords: economic system, business and monetary transaction, and Buginese pandeling.

\section{Introduction}

Pandeling is based on the word of verpandeling, that referred to a basic word pand. In Dutch language, the term of pand means a guarantee. So, pandeling is someone that guaranteed him-or herself to get a credit or to lend some money. Thus, the terms of pandeling and verpandeling cannot be separated from a connotation on guarantee or insurance. In practice, the terms of verpandeling and pandeling are used legally as well as economically to refer the activities that provided some guarantee of someone to another as a duty to get something. ${ }^{1}$

In the past economic system, the above mentioned transaction was one of economic interactions that based on social ties and traditions. The tradition was recognized legally and routinely as a form of market transaction and even as an institution. Verpandeling, as a part of economic transaction, shows the interaction between one side and another side, which the first one provides a guarantee to another for getting a loan to add a capital investment. The loan can be a cash value, means of production, equipment or a certain facility that support his bussiness.

${ }^{1}$ Among Malays in the past, pandeling was known as utang badan, because he used his physic as a guarantee for his debt. But for being a pandeling, it needed a deal between debtor and creditor, so that the relation would be voluntarily. D.W.C. Baron van Lynden en J. Groll, "Aantekeningen over de landen van de stroomgebied der Kapoeas” dalam Natuurkundig Tijdschrift voor Nederlandsch Indië, 1851, vol. 2, p. 628. 
However, it is important to note that it is not loan that provided, but guarantee for getting the loan that offered. If in the legal economic modern, the form of guarantee is generally unmovable things as grond and effect or obligation, with verpandeling the guarantee is human being that to be able to work. The human can be consisted of member of debtor's family, subordinates (numpang), his/her slaves, but also him- or herself as guarantee for the loan. Humas a guarantee for getting a credit or loan is called as pandeling. (iemand, die zich voor een schuld persoonlijk verbind en daarvoor moet werken bij den schuldeischer of bij hem aan wien deze dat recht heeft overgedaan). ${ }^{2}$

To define this term, a following concept of pandeling can be seen:

Een pandeling is een vrij person op wiens een ander pandrecht uitoefend met de bevoegdheid zijne diensten te gebruiken totdat de schuld, die ten alleen tijde voldaan kan worden, afgelost is. De pandeling kan of zich zelf, of anderen die in zijn macht zijn, b.v. zijn kind, in pand gegeven hebben, bij het opnemen van geld, dan wel in pandbeslag zijn genomen, wanneer hij een schuld niet op den overeengekomen vervaldag heeft betaald. Als grondslag van pandelingschap strekt dus een schuld. ${ }^{3}$

A pandeling is a free person that guaranteed by another that having a right for collecting his services to the repayment of loan. Pandeling can provide himself or another who under his authority as his child, as a guarantee in getting a credit, except in seizure of collateral if he cannot pay off the loan at the agreed paying time. Thus, the basic of pandeling transaction is a credit or loan.

Beside the above definition, definition of pandeling cannot be separated from the context of legal economy that regulate the transaction with their actors. It is noted that there is a money as a medium of exchange and a legal medium for payment. Although it is clear that in a traditional pre-industry community, escpecially in Oriental, the credit transaction was found, the transaction is rather limited to the exchange of production means and has a temporarily in character without some legal regulations. For example, in traditional peasant community, there was a usual borrowing of agricultural seeds one and another, and to return in form of the production. It was applicable for plantation and also for livestock. ${ }^{4}$

In a modern industrial society, that regulated and motivated by a monetary transaction as a foundation of its economic structure, a such form of borrowing is not anymore. The transaction is regulated by a formally agreed standard in an economic system. There is no a borrowing of production means or sources, but all are defined by a

2P.A. van der Lith, Nederlandsch Oost Indië (Leiden: E.J. Brill, 1893), p. 346. Because Lith supposed that pandeling was based on a common law, there is a probability that Lith in this case equated pandeling to slave, especially hereditary slave (erfslaverij), because the debt tradition in Western economic concept was hardy known in Oriental.

3"Pandeling, Pandelingschap" in D.G. Stibbe, Encyclopaedie van Nederlandsch Indië, derde deel ('s Gravenhage, 1919, Martinus Nijhoff), p. 281.

${ }^{4}$ Fokkens stated that the system was a source of peasant's motivation to make a debt as he needed any cash suddenly in a great number, for example to make an intent. According Fokkens, with this way, peasant had hardy any save or capital accumulation. F. Fokkens, "The power of money-lenders in Java", in M.R. Fernando and David Bulbeck, Chinese Economic Activity in Netherlands India (Singapore: Institute of Southeast Asia Study, 1991), p. 45. 
fiscal value that function as a guideline and measure of transaction. ${ }^{5}$ Thus, pandeling can be defined as a transition between a traditional borrowing system and a credit transaction in a modern economic system.

Another aspect that played an important role in pandeling, related with a modern credit system and traditional borrowing of production means is a form of rent. In money loaning of modern credit system in monetary industrial economy, rent factor has a significant part as a surplus value and a motivation to provide a credit by creditor, beside a value of guarantee provided by debtor. Rent is often regarded as a product of credit. However, principally rent is a surplus value, especially as double rent is applied in the transaction. ${ }^{6}$

As the result of the credit, transaction shows an increase of escalation, particularly with double rent, the loaning business develops into a transaction. As a form of transaction, with the growth of credit institution as an investment, credit system expands to be an institutionalized savings-and-loan system. Therefore, administrative system dominates the transaction too, as the creditor has a credibility and legality to provide a guarantee of credit. Based on the credibility, the institution can provide a written credit (bilyet) as a guarantee. This bilyet functions as a form of property that invested in the credit institution, and a right to levy a rent on the invested capital. ${ }^{7}$

The credit is used not only as a capital liquidity guarantee but also functioned as a mean of exchange, as the bilyet can be traded in the context of the modern market economic transaction. The process in trading bilyets is one of the crucial characteristics of the modern monetary system.

The system finally expands geographically and influences another system in the Eastern hemisphere with a different structure. The relation in the intercontinental transaction with included various ethnics motivated an international transaction with a various system. In this interaction, exchange of economic values that apply to each system cannot be avoided. In this case, credit system and rent in Western hemisphere began to expand to Eastern hemisphere and finally adopted as long as regarded profitable for business.

The profit factor and the absence of legal regulation that applicable as a formal foundation of economic system motivated a value exchange as an integral part of the transaction. One of them is credit and rent. As loaning system in the Oriental traditional economic system was based on a credibility and the products, Western credit system has an effect on the growth of monetary value as a standard measure in the Oriental credit transaction. Thereof, the system for rent calculation cannot be avoided. Now, the relation of capital loan is not defined as a model for a traditional sharing system of production but calculated as a running capital, namely with a rent as a surplus value on the invested capital. Although there was not yet a bilyet in the Oriental transaction system, the credit transaction and rent dominated some center of economic activity in 17th century Asia.

\footnotetext{
${ }^{5}$ In this community, credit or loan was an integral part of investment system and capital exploitation. It is clear as any competition borne for getting any target of production, so that modal was needed to reach it. John Weeks, Capital, Exploitation and Economic Crisis (Oxon: Routledge, 2010), p. 111.

${ }^{6}$ Rent as a surplus value was levied as there was any idea that rent was a part of production process with any capital. This rent was regarded as a new component in production cost, because it was seen as a surplus value on a basic capital effectively. Knut Wicksell, Value, Capital, and Rent (Alabama: Ludwig von Mises Institute, 2007), p. 38.

${ }^{7}$ Formally, this rule was published in Java Courant, dated 7 Oktober 1845 no. 85, that stated that bill or bilyet of a bank or wissel could be sold with silver gulden value and representative of a bank bilyet (bankpapier). J.H. Meiss, Eenige Bijdragen tot de Kennis van den Inwendigen Toestand van Ned. Indië Onder Bestuur van Gouverneur Generaal J.J. Rochusen (1845-1851) (Leiden: Brill, 1883), p. 8.
} 
The above condition has an influence on a loaning system with the human guarantee (pandeling) as mentioned above. By the pandeling system, someone who has a loan must pay off his loan to get his freedom. They had to work for their creditor for a certain time to install his credit or repaid by his family so that he can be freed from his pandeling status. If the loan is not paid, he will be a guaranteed man and has a duty to work for his creditor forever. ${ }^{8}$

As Western credit system expanded into the orietal market system, its effects were felt on the pandeling system. With a surplus valued that defined by monetary scale, the pandeling system changed. Since the 18th century, pandeling had no a compulsory to work for paying his loan, but his energy and time that devoted has been calculated as a form of loan paying to his creditor. So, energy and time of pandeling were regarded as a value and a part of production cost, as a fabricate production system.

The above change, however, does not mean positively for pandeling, because the creditor applied a changing calculation model for his loaned money. With the appllication of Western rent system, creditor calculated a rent on his debt on pandeling. It means that total of pandeling's debt grows more and more as he must pay off it, than the loan before. The increase of surplus value is calculated with the pandeling's working time for creditor, that refer a more duties and burdens for him. ${ }^{9}$

Beside the above mentioned effect, pandeling was not regarded as a monopoly right of his creditor. As a bank bilyet, pandeling could be transferred to another creditor if his owner needed a cash of money and traded his pandeling. ${ }^{10}$ the way for meeting the need is to transfer his pandeling with the total of uninstalled debt plus a calculated rent. Another person that paying the total has an authority on pandeling with a right to reap his services and pandeling will be tied to his new creditor. ${ }^{11}$

Thus, pandeling is a trade commodity in business and monetary transaction among the traders and capital investors. Pandeling came into the system without prediction to be transferred and even had to separate from his family, if the new owner came from far away. According the formal regulation on this transaction, pandeling had to subordinate except he could pay off his debt with all rents. After his debt and rent was paid off by himself, pandeling did not often return to his original place but lived in his new settlement, place where he got his freedom. Therefore, this group will begin as a part of local community or build a new community as a free person.

\section{Bugis Diaspora in East Borneo}

${ }^{8}$ However, if pandeling died under his working time, his wife or children did not replace him, although it is depended on the deal between pandeling and his creditor. So when he would marry, pandeling needed no any permission to his creditor. It differentiated him with a slave that subordinated totally to his master or owner, included hishereditary status to his children. R.C. van Prehn, "Aantekeningen Omtrent het Borneo Westkust”, dalam Tijdschrift van Bataviaasch Gennootschap, vol. VII, 1858, p. 32.

${ }^{9}$ In this case, creditor was known as the holder or owner of guarantee (pandeigenaar). The uniqueness is a fact that he was not a total true owner but the owver of guarantee right (pandrecht), that being burdened with a surplus value or transferred to another creditor as a collector (schuldeischer). Julius Christiaan van Oven, Leerboek van Romein Privaatsrecht (Leiden: E.J. Brill, 1946), p. 180.

${ }^{10}$ In Bencoolen, this process was called as manghiri. Under British control, the process was regulated so that it provided any guarantee and protection for pandeling. Hubertus Gerardus Nahuys van Burgst, Schets van Benkoelen op de Weskust van het Eiland Sumatra (Batavia: Landsdrukkerij, 1825), p. 220.

${ }^{11}$ As a basic for this system is article 1812 of Burgerlyke Wetboek, saying that a guarantee can be sold by its creditor or transferred by another way or used as a guarantee to any debt collector, as land in hypotic system. In a following article, 1814, guarantee right can be got by creditor through any dewal for another debts (pandregt kan bij overeenkomst toegestaan worden tot merdeere verzekering van allerlei soorten van schulden). Het Nederlandsch Burgerlijk Wetboek: de Code Civil van het Wetboek Lodewijk Napoleon en het Burgerlijke Wetboek met Verwijzigen (Leiden: J.H. Gerhard, 1850), p. 391. 
The Bugis, an ethnic that lived in South-western Sulawesi (Celebes), is a social and culture community that establishing her hegemony in various aspects in Nusantara Archipelago. In the past, their domination did not limit to their local area, but they dispersed to another locations outside Sulawesi island, even outside Indonesia Archipelago. ${ }^{12}$

As a maritim nation, included river, coastal, sea and ocean shipping, the Bugis had explored a vast waters around their oroginal location and even cruised to another islands. Their adventure was motivated by their ambition to seac=rch for a new location as an area for the better living style than before. In her history, at least there were some waves of a great migration that motivated by political conditon and forced them to look for a new settlement and livelihood. 13

As a nation and socio-cultural unit, this ethnic has traditional values as her local identity but also functions to support their existence and domination on a certain territoral unit. The values that grow from habit and behavior of live and the interaction are used as social norms and rules that applied by all members of ethnic as a basic of their social relation and structure. ${ }^{14}$

When a member left his original habitat and explored to around waters, he called at the certain locations. Although it was temporarily in character, wether to get a supply or for local orientation, in some places they stopped and built a permanent settlement. The pattern was followed by many members of the ethnical group so that they built some new settlements separated from their original place geographically. These new settlements that spread in some islands of Indonesia in $16^{\text {th }}-18^{\text {th }}$ century, was called as Bugis diaspora. ${ }^{15}$

The location that visited by this ethnic cannot be separated from their sailing and trading activities, as their maritime socio-economic background that depended their livehood on this sector. Based the fact, the Bugis settlement centers in general were along the coast that being a trade and shipping route in the past. Some small islands that lied in strategic route were also built as their settlement and maritime bases. ${ }^{16}$

In their new places, with different cultural background and showing the difference with the migrants' culture, the Bugis tried to make any interaction and mixed with local ethnic and culture. However, the basic principle was still hold, namely they came as a

${ }^{12}$ The Bugis superiority in this process is a fact that they act as a trader and at the same time as a sailor that sailing for a greate distance voyage. Therefore they are known as a trader, rover, and local ruler after estabilishing his permanen settlement. Donald B. Freeman, Straits of Malacca: Gateway or Gauntlet? (Quebec City: McGill Queen University Press, 2003), p. 157.

${ }^{13}$ B. Schrieke, Indonesian Sociological Studies, part one (The Hague: W. van Hoeve Ltd., 1955), p. 229. Schrieke said that Bugis migration was taken place after Makasar was controlled by VOC and Company applied a trade monopoly there, so that many Bugis sailors had no any freedom ans left South Sulawesi. But any another idea comes namely Bugis migration was taken place befor that, as Islamisation process was launched by Goa that followed by Goa expansion to Bugis kingdoms. A major migration of Bugis was taken place because they did not subordinate to Goa.

${ }^{14}$ Many authors said that any ethnical ties based on kinship is more important among the Bugis than territorial ties. V. Korn, "Problemen der Makassars-Boeginese samenleving" in BKI, vol. 108, no. 1, 1952, p. 25-26.

${ }^{15}$ Leonard Y. Andaya, "The Bugis-Makassar diaspora”, in Borneo Research Bulletin, vol. 26-28, 1995, p. 201. Bugis migration must be distinguished with Makassar migration. Makassar migration was consisted of political elites and noblemen, meanwhile the Bugis was consisted of common people. Economic factor motivated Bugis more than Makassar, that motivated by political one, namely their defeat in war 1669 againts VOC.

${ }^{16}$ Hikayat Negeri Johor in the middle of $17^{\text {th }}$ century said about a Bugis dynasty that controlled some islands in Riau archipel around Johor. Penyengat island was a main basis for Bugis as sailors. They were used not only economically but also politically so that they found any chance to participate in local political constellation. Carl A. Trocki, Prince of Pirate: the Temenggongs and the Development of Johor and Singapore, 1784-1885 (Singapore: NUS Press, 2007), p. 23. 
maritime nation and tried to apply their cultural values as a dominant norm in their new settlement. Through their smart strategy and capability, this ethnic can reach their goal. It is proved by the fact that it is hardy past notes that showing any rejection or expulsion by the local population againts this ethnic. ${ }^{17}$

However, not all location that they visited was a no man's land. Some places where the Bugis built their settlement was an area under or annexed by another political power, even the dominant local political institution. Facing the existing structure, the Bugis migrants had to adapt themselves or at least to have a strategic bargaining position for the balance interaction toward local powers. In some places as Ternate, Mollucas islands, Riau archipel and Malay peninsula, this strategy was applied succesfully so that the Bugis got a dominant position and their diaspora could be hold for some centuries. ${ }^{18}$

One of their new settlements and under local power is East Kalimantan. In easten coast of Kalimantan island, some local kingdoms as Kutai Kertanegara, pasir, Bulungan and so on dominated. As another coastal area in Middle and Eastern indonesia, along coast was a target of Bugis migrant's visit and after that, settlement of Bugis sailors. They came in this place in the early 17th century when Sultanate Gowa in South Sulawesi expanded her power to northern (Bugis areas). The short distance and favourable local potential, although outside the maritime main route in $17^{\text {th }}$ century as Mallaca and Java, made the areas interesting for the maritime ethnic.

From anthropology-history studies, there were elements that motivated the Bugis migrants to East Kalimantan. According their opinion, there is a legend that telling that the origin of Bugis was a maritime ethnic that settled a place around Kutei-Samarinda or Pegatan-Pulau Laut. Both are in east-coast of Kalimantan that spread to southern. According this story, the people migrated through coastal sailing routes and settled an area around estuary of Sadang river. Thus, if the Bugis migrants visited Kutai, it can be concluded that they returned to their original area. ${ }^{19}$

After cultural ties, geography motivated any complex and routine interaction between two places. Calm and narrow waters of Makasar strait provided a potential for Bugis small and middle scale boats from western coast of Sulawesi, especially from ParePare, Palopo, and Makasar for sailing to visit eastern coast of Kalimantan, and vice verza. However, based on a political background, the $16^{\text {th }}-17^{\text {th }}$ century economic maritime system in Makasar strait was used more by the Bugis that settled in South Sulawesi than people of east Kalimantan. More and more Bugis came to Kalimantan than the opposite. ${ }^{20}$

${ }^{17}$ One of them is a fact that Bugis brought their capability in casting gold and another precious stones. In Malay peninsula and Riau archipel, Bugis diaspora was known as center for precious stone industry that interesting for local elite there and support their influence among Malay noblemen. Anne Richter and Bruce W. Carpenter, Gold Jewellery of the Indonesian Archipelago (Singapore: Didier Millet Pte. Ltd., 2011), p. 36.

${ }^{18}$ Leirissa said that some Bugis sailors and traders even could penetrate the prevailing social structure, although with any risk. For example, in the late $17^{\text {th }}$ century an official of VOC rapported that they caught some Bugis traders because they broke economic boundaries in North Mollucas and sentenced to death or sent as a slave to clove plantation in Banda. R.Z. Leirissa, "The Bugis-Makassare in port towns Ambon and Ternate through the nineteenth century", in BKI, Vol. 156, 2000, p. 623.

${ }^{19}$ Christian Pelras, The Bugis (Massachussetts: Blackwell Publishers, 1996), p. 42. Antropology research shows that there is a proof of similarity between two languages and cultures of ethnics, namely Bugis and East Kalimantan, since the past. As it is found that language among the Bugis has an origin in East Kalimantan, it can be said that the idea is true. But if the opposite comes, it is clear that native people of Kalimantan is receiver of Bugis culture and it is taken place in the recent time.

${ }^{20}$ Majority of Bugis that visited East Kalimantan are traders or common people that has any relation with business community in South Sulawersi. Based on this network, economic exploitation in their diaspora could continue routinely and savely. Burhan D. Magenda, East Kalimantan: the Decline of a Commercial Aristocracy (Singapore: Equinox publ., 2010), p. 13. 
Since early $17^{\text {th }}$ century, Bugis sailors established their position in two political and economic central locations in East Kalimantan, namely Pasir and Kutai. By exploiting the local native elite's weakness and their routine interaction, the Bugis slowly but surely dominated a social, economic and political system of both. The climax came in 1726, when a noble of Wajo that survived from his original place because of political conspiracy, named Arung Singkang, installed himself as a ruler of both. Though he returned to South Sulawesi in 1735, the Bugis influence on both was still dominant until $19^{\text {th }}$ century. ${ }^{21}$

In this diaspora, the Bugis cannot loose her cultural character as a maritime ethnic. After controlling waters around ports or main bussines places, they controlled main river routes as an artery of domestic trade. The Mahakam river that functions as the only route between production area in hinterland and center pf export-import in coastal area became a main settlement location of this ethnic. Therefore, in early 19th century some towns as Samarinda, Pulau Laut, Pegatan, Pasir, Kutai, Bulungan, Berau and gunung Tabur grew as Bugis diasporas. ${ }^{22}$

After establishing her economic position, they had a bargaining position for local ruler to guarantee her political domination. Arung Singkang's succesor, La Ma'dukelleng, as a Bugis local ruler in Kutai, built a cultural relation with a local ruler by marrying his son to one of Sultan Pasir's daughter, and then his daughter married with Sultan Idris of Kutai. Both steps, among the others, made Bugis elite as a political and economic dominant power in their diaspora. ${ }^{23}$

\section{Pandeling among the Bugis}

Beside establishing their political and economic domination in the new areas that they visited and controlled, the Bugis brought their cultural values to their new settlements and applied them there. These cultural values were not only hold as an identity symbol but also functions to support their dominant position and social hegemony.

One of traditions as a socio-economic value was debt relation with a human guarantee (pandeling). Among the ethnics in South Sulawesi, the Bugis had a debt relation inter-individuals in their cultural system ${ }^{24}$ This relation, that has no connection with a modern bussiness system, based on the traditional habit and opinion that every Bugis

${ }^{21}$ Gerrit Knaap and Heather Sutherland, Monsoon Traders: Ships, Skippers, and Commodities in Eigthteenth Century Makassar (Leiden: KITLV, 2004), p. 14. Kutai and Pasir had been visited by Bugis sailors since $16^{\text {th }}$ century, as Makassar guaranteed any freedom to all ethnics in South Sulawesi, included foreigners for establishing a dinamyc of socio-economy condition in that port, in relation with another center of production. See also p. 18.

${ }^{22}$ Robert Cribbs, Historical Atlas of Indonesia (Surrey: Curzon Press, 2000), p. LXIII. Cribbs says that Bugis has a significant role in the establishment of Pasir Kingdom. Meanwhile any anoter sources said that Pegatan Kingdom was also built bu the Bugis migrants. Thus in their diaspora, the Bugis dominated not only economy but also politic. Jan van Baal, Besturen Oversee: Herinneringen van oud Ambtenaar bij het Binnenlands Bestuur in Nederlandsch Indië (Franeker: Wever, 1977), p. 313.

${ }^{23}$ One of proofs of their strategtic success is a fact that Arung Singkang finally sit on the throne of Pasir Kingdom. Beside to genealogy, this fact showed any symbolic winning of the Bugis on a local people. J. van Goor, Generale Missive van Gouverneurs General en Raden aan Heren XVII der Vereenigde Oost Indische Compagnie, vol IX, 1725-1729 ('s Gravenhage: M. Nijhoff, 1985), p. 76. Nevertheles, in historical sources of Pasir, the Bugis' role was not expressed but only mentioned casually and their chief was installed as a captaint like Wajo. A.H.F.J. Nusselein, "Beschrijving het landschap Pasir", in BKI, vol. 58, 1905, p. 566. Only Aru Paneki was mentioned and destined to fail in ruling Pasir.

${ }^{24}$ For Bugis and Makassar, debt relation was an important one in their economic system. It is proven by an archive of VOC dated 8 Desember 1742 that told us that any emissary from Wajo, La Taning, coming in Makasar for any permission to Wajo traders returning to the city after the peace agreement was made. The first action is to search some people who still had any debt and collected them. J. Noorduyn, "The Wajorese Merchants Community in Makassar", in BKI, vol. 156, 2000, p. 484. 
who can prove himself as the owner of unmovable things (onroerende goederen) as his private source, had a right to work, to make any production, and even to guarantee (verpand) to another individual for the sake of profit or if he must meet any urgent needs. ${ }^{25}$

Because a strong communal system dominated any social ties among the Bugis, in coastal as well as in hinterland area, loosing a right to another was forbidden. They were permitted by their collective ties to loose for temporarily for the urgent profit. Thus, there was no eternal right loosing as selling something. It was applicable for individual in the ethnic, that forbidden to make any buying on unmovable things.

However, in practice, this rule was applicated to movable things (roerende goederen). It came when the movable things had a significant role in production process to get any product. For example, it was applicated to boat, farming equipment, hunting equipment, even materials for building a house. By borrowing these movable things, loan or credit in the context of modern economy spread and get into production process. Thus, in borrowing the movable and unmovable things, process of pandeling remained applicable and increasingly found among community. ${ }^{26}$

Beside institution of slavery that known in South Sulawesi among the Bugis, ${ }^{27}$ pandeling gave a special identity to this ethnic compared with another in Indonesia. It is a sign that credit transaction has been found among them before credit and economic system of Western model appeared in their business activities. With this pandeling, status of semi-slave who had a loan to another could be found in the Bugis' social life, particulary among persons that provided a credit and appeared in their patron-client relation. ${ }^{28}$

This tradition was spread to the Bugis' diasporas, included in East Kalimantan with the same structure and civilization. ${ }^{29}$ In this location, the Bugis lend each other the production means based on credit system. Thus, among them it was found status of pandeling. As the process took place among the Bugis, they applied their prevailing values. But the problem is different when the Bugis interacted and involved in the borrowing process to another ethnic, namely Malays, Dayak or Banjars, that had any population in East Kalimantan.

In their daily relation and interaction, borrowing could be taken place. Some people that had an urgent need of means for increasing their production or another goal would

25“Buginese" in D.G. Stibbe, Encyclopaedie van Nederlandsch Indië, eerste deel ('s Gravenhage: Martinus Nijhoff, 1917), p. 330.

${ }^{26}$ The increasing and spreading of pandeling was taken place because every individual had a risk to burden it, include king's family and noblemen. But in general, they who had a debt was not treated or diven a status of pandeling. Instead of himself, he could order his subordinates to replace him. F.N. Nieuwenhuijzen, "Het rijk Siak Sri Indrapura", in Tijdschrift van Bataviaasch Gennootschap, vol. 7, 1858, p. 417.

${ }^{27}$ The Bugis is one of ethnics in Indonesia that known to hold a slavery system, politically as well as economically. With the greater wars, a potential for getting many slaves that coming from prisoners of war is so great. They were not only kept but also traded as a commodity, often with their master's adventure to another area. Anon, "Slavernij in Indië", in De Indische Gids, vol. I, 1924.

${ }^{28}$ There are five components that creating the Bugis social structure and it can be realized in their diaspora: traditional social position, patron-client relationship, economic strategy, kinship and communal ties to geographic location. All of them can not be separated but develop into a patron-client relationship between creditor and debtor. Greg Aciaioli, "Kinship and debt: the social organization of Bugis migration and fish marketing at Lake Lindu, Central Sulawesi”, in Bijdragen tot Koninklijk Instituut (BKI), vol. 156, 2000, p. 592.

${ }^{29}$ In some area with unbalance civilization, the process of pandeling could not be found. For example, in Papua or in Ambon in early 17th century, although Bugis trader community played a significant role and had a potential for applicating a debt system to get any pandeling, in the rapport there is no information and supposed because local people did not understand about the status except as a slave. Gerrit Knaap, Kruidnagelen en Christenen: de Verenigde Oost-Indische Compagnie en de Bevolking van Ambon 1656-1696 (Leiden: KITLV Uitgeverij, 2004), p. 170. 
look for someone that being able to meet them by borrowing with guarantee (verpand). The self-guarantee borne the status of pandeling, for getting a boat, land or production means. As the Bugis lent his equipment and got a pandeling, the debtor had to work for him and set aside a part of product as an installment of his debt. The pandeling would get his freedom after he could pay off all his debt. ${ }^{30}$

Based the pattern, pandeling had to live or at least to work for his creditor as a duty and debt ties. Therefore in a certain time, they remained in credit relation. However, as the creditor wanted to return to his origin place, namely in South Sulawesi and his pandeling had not yet paid off his debt, the relation would remain. As a consequence, pandeling had to follow his debtor in going to South Sulawesi. Coming in South Sulawesi, form of devotion based on credit system would continue as in the diaspora.

On the deck of ship, it was found many change as result of a system. When two factors came, namely rent and trade system of pandeling, transaction of pandeling in sea was often taken place. With a rent calculated on the debt that burdened by pandeling, he did not set aside a part of product to his creditor anymore but all products, meanwhile he would get a little procentation from his creditor for meeting his primary needs and his family. ${ }^{31}$ So, paying of his debt was not defined by share cropping but by the value of product, as value standard was applicated on the debt because of rent.

On the ship's deck, pandeling did not work because there was no means or capital to work out, so that he sold his energy to creditor. Therefore, a time calculation was used for calculating the paying off. So, one day or one week working on the deck would be calculated with a certain product when he worked in land, and the product would be used to pay off his debt. In nineteenth century, many pandelings were found on the deck that sailed between East Kalimantan and Makasar or Pare-Pare and they lived like slaves, worked for his debtor to paddle, to clead the deck, to bring something and so on. The difference between both was their physical appearance that in general not chained. After coming in a port, he was regarded to pay off the debt or at least to minimalise it. Thus, it was found that after leaving the ship, pandeling was not a creditor anymore but a free person without any ties to his debtor.

However, the problem will be complex in the second fact, namely in trading or transferring a pandeling to another debtor as a bilyet or bill. This process was not only taken place in land or port but also on the dect as debtor sailed with his pandeling. As a transaction was taken place on the deck and any offer for transferring the debt with its rent, or as a debtor suddenly needed some money in urgent condition, he got any transaction with another that provided an interesting offer for taking over his debt and automatically his pandeling.

This deal on deck was a beginning of a process how a pandeling changed his master as he gave his pandeling formally with all bills to another. The another crteditor with his paying for the debt in cash would get any authority over pandeling. As the ship anchored and all passangers landed, pandeling remained to work as before but he had a new master. In this process, pandeling could adventure far away according his new master's will. ${ }^{32}$

${ }^{30}$ Anwar Thosibo, Historiografi Perbudakan: Sejarah Perbudakan di Sulawesi Selatan Abad XIX (Magelang: Yayasan Indonesiatera, 2000), p. 152.

${ }^{31}$ In the middle of $19^{\text {th }}$ century Dutch colonial government realized the status of pandeling and did not abolish it. The policy was only to protect a pandeling against his debt collector physically, and when the change came in a way to pay off the debt with energy, government guaranteed that pandeling would get any food from his creditor (hetgeen den pandeling voor voedsel voorkomt, moet hem, te zijner keus, hetzij in natura, hetzij in geld worden versterkt). Staatsblad van Nederlandsch Indië 1858 no. 43.

32 S.W.Tromp,"Eenige medeedelingen omtrent de Boeginezen van Koetei" in BKI, 1887, vol. 36, page 194. Person who transferred as pandeling from one to another creditor was called as tau manginrang ulu, that means a hereditary slave. In the past, it was taken place when a creditor had a debt to another and 
This fact could be more complex when pandeling experienced more than one changing of master, as his creditor resold him for paying off to another creditor. Therefore, although there was any difference between pandeling and slave, in principle any equation is found namely human subordinated to another as an object of commodity. ${ }^{33}$

\section{Conclusion}

The transaction on a ship's deck with pandeling and his debt ties is an economic phenomenon as a proof of modern economic system on a pattern of the transaction in the traditional system. Rent and guarantee trade is a new factor and they can change the traditional economic structure. Both are complex as related to any guarantee of human in debt.

Among the Bugis, that based on maritime culture, namely maritime trade, the change creates a new pattern in the prevailing economic structure. Pandeling did not work anymore with his agrarian production as the basis of calculation, but with his energy and time, because he had to work on the deck. Value calculation of energy and time that consumed can function as a standard for calculating a loon in a certain form of money.

With this change, in practice, this system continued inland, depended on the deal between pandeling and his creditor. When the system remained, the calculation of value unit will be a basis for loon calculation that provided to someone who works in plantation or another production facility in the land. In South Sulawesi, that opened for a capital inflow of plantation industry in the late nineteenth century, the value standard was very significant to define a loon scale for plantation worker and another industrial worker, include docker.

\section{References}

Baron van Lynden, D.W.C. en J. Groll. "Aantekeningen over de Landen van de Stroomgebied der Kapoeas." In Natuurkundig Tijdschrift voor Nederlandsch Indië, vol. 2, 1851.

Lith, P.A. van der. Nederlandsch Oost Indië. Leiden: E.J. Brill, 1893.

Stibbe, D.G. Stibbe Encyclopaedie van Nederlandsch Indië, derde deel. 's Gravenhage: Martinus Nijhoff, 1919.

Fokkens, F. "The Power of Money-lenders in Java." In M.R. Fernando and David Bulbeck, Chinese Economic Activity in Netherlands India. Singapore: Institute of Southeast Asia Study, 1991.

Weeks, John. Capital, Exploitation, and Economic Crisis. Oxon: Routledge, 2010.

Wicksell, Knut. Value, Capital, and Rent. Alabama: Ludwig von Mises Institute, 2007.

Java Courant, 7 Oktober 1845 no. 85.

Meiss, J. H. Eenige Bijdragen tot de Kennis van den Inwendigen Toestand van Ned. Indië Onder Bestuur van Gouverneur Generaal J.J. Rochusen (1845-1851). Leiden: Brill, 1883.

Prehn, R.C. van. "Aantekeningen Omtrent het Borneo Westkust." Tijdschrift van Bataviaasch Gennootschap, vol. VII, 1858.

pandeling was used as a guarantee. When the first one could not pay off his debt, the second would take over pandeling.

${ }^{33}$ H.W. Daendels, Staat van Nederlandsch Oost Indische Bezittingen Onder Bestuur van Gouverneur Generaal Herman Willem Daendels (Den Haag, 1814), afdeeling Java Noordoostkust, nomor 4. Among Dutch high officials in $18^{\text {th }}-19^{\text {th }}$ century, it was hard to distinguish between pandeling and slave, especially they who owned by Europeans or native elite. Because of a same bad treatment to them, both could be equated and classified. Meanwhile, both came from different context, although they were created because of inability to pay their debt. Th. S. Raffles, History of Java, vol. II (London: John Murray, 1830), p. c. 
Oven, Julius Christiaan van. Leerboek van Romein Privaatsrecht. Leiden: E.J. Brill, 1946.

Burgst, Hubertus Gerardus Nahuys van. Schets van Benkoelen op de Weskust van het Eiland Sumatra. Batavia: Landsdrukkerij, 1825.

Het Nederlandsch Burgerlijk Wetboek: de Code Civil van het Wetboek Lodewijk Napoleon en het Burgerlijke Wetboek met Verwijzigen. Leiden: J.H. Gerhard, 1850.

Donald B. Freeman. Straits of Malacca: Gateway or Gauntlet?. Quebec City: McGill Queen University Press, 2003.

B. Schrieke. Indonesian Sociological Studies, part one. The Hague: W. van Hoeve Ltd., 1955.

Korn, V. "Problemen der Makassars-Boeginese samenleving" in BKI, vol. 108, no. 1, 1952.

Andaya, Leonard Y. "The Bugis-Makassar Diaspora." In Borneo Research Bulletin, vol. 2628, 1995.

Trocki, Carl A. Prince of Pirate: the Temenggongs and the Development of Johor and Singapore, 1784-1885. Singapore: NUS Press, 2007.

Richter, Anne, and Bruce W. Carpenter. Gold Jewellery of the Indonesian Archipelago. Singapore: Didier Millet Pte. Ltd., 2011.

Leirissa, R.Z. "The Bugis-Makassare in Port Towns Ambon and Ternate through the Nineteenth Century", BKI, Vol. 156, 2000.

Pelras, Christian. The Bugis. Massachussetts: Blackwell Publishers, 1996.

Magenda, Burhan D., East Kalimantan: the Decline of a Commercial Aristocracy. Singapore: Equinox publ., 2010.

Knaap, Gerrit and Heather Sutherland. Monsoon Traders: Ships, Skippers, and Commodities in Eigthteenth Century Makassar. Leiden: KITLV, 2004.

Cribbs, Robert. Historical Atlas of Indonesia. Surrey: Curzon Press, 2000.

Baal, Jan van. Besturen Oversee: Herinneringen van oud Ambtenaar bij het Binnenlands Bestuur in Nederlandsch Indië. Franeker: Wever, 1977.

Goor, J. van, Generale Missive van Gouverneurs General en Raden aan Heren XVII der Vereenigde Oost Indische Compagnie, vol IX, 1725-1729. 's Gravenhage: M. Nijhoff, 1985.

Nusselein, A.H.F.J. "Beschrijving het Kandschap Pasir”, BKI, vol. 58, 1905.

Noorduyn, J. "The Wajorese Merchants Community in Makassar", BKI, vol. 156, 2000.

Stibbe, D.G., Encyclopaedie van Nederlandsch Indië, eerste deel. 's Gravenhage: Martinus Nijhoff, 1917.

Nieuwenhuijzen, F.N. "Het rijk Siak Sri Indrapura", Tijdschrift van Bataviaasch Gennootschap, vol. 7, 1858.

Anon. "Slavernij in Indië", De Indische Gids, vol. I, 1924.

Aciaioli, Greg. "Kinship and Debt: the Social Organization of Bugis Migration and Fish Marketing at Lake Lindu, Central Sulawesi", Bijdragen tot Koninklijk Instituut (BKI), vol. 156, 2000.

Knaap, Gerrit. Kruidnagelen en Christenen: de Verenigde Oost-Indische Compagnie en de bevolking van Ambon 1656-1696. Leiden, KITLV Uitgeverij, 2004.

Thosibo, Anwar, Historiografi Perbudakan: Sejarah Perbudakan di Sulawesi Selatan Abad XIX. Magelang: Yayasan Indonesiatera, 2000.

Staatsblad van Nederlandsch Indië, no. 43, 1858.

Tromp, S.W. "Eenige Medeedelingen Omtrent de Boeginezen van Koetei" BKI, 1887, vol. 36.

Daendels, H.W. Staat van Nederlandsch Oost Indische Bezittingen onder bestuur van Gouverneur Generaal Herman Willem Daendels. Den Haag, 1814.

Raffles, Th. S. History of Java, vol. II. London: John Murray, 1830. 